\title{
Literasi Digital Bagi Siswa Sekolah Menengah Pertama Aisyiyah Muhammadiyah 3 Malang
}

\author{
Hidayah Budi Qur'ani ${ }^{l)}$, Purwati Anggraini ${ }^{2}$ \\ ${ }^{1), 2)}$ Program Studi Pendidikan Bahasa Indonesia, Fakultas Keguruan dan Ilmu Pendidikan, \\ Universitas Muhammadiyah Malang, Indonesia
}

Corresponding author: Hidayah Budi Qur’ani, qurani@umm.ac.id

\begin{abstract}
Abstrak: Masa remaja merupakan masa peralihan dari masa kanak-kanak hingga dewasa. Masa remaja biasanya diikuti dengan proses penemuan diri. Dalam hal ini, biasanya remaja ingin mencari tahu sesuatu yang tidak mereka ketahui, ingin keberadaannya diperhatikan, dan cenderung lebih bergaul dengan teman sebayanya. Perkembangan teknologi saat ini juga sangat mempengaruhi perkembangan remaja. Setiap siswa memiliki satu perangkat yang dapat digunakan untuk berkomunikasi dan mengakses berbagai informasi yang dapat mendukung pembelajarannya. Oleh karena itu, diperlukan bantuan literasi digital bagi siswa sekolah menengah pertama. Pengabdian ini dilakukan melalui tiga tahapan, diantaranya tahap persiapan, tahap pelaksanaan, dan tahap refleksi. Pada tahap persiapan terdiri dari koordinasi dengan pihak sekolah dan koordinasi dengan pendamping siswa. Tahap pelaksanaan terdiri dari pemberian materi, diskusi, pendampingan siswa, dan produk siswa. Kemudian tahap refleksi terdiri dari hal-hal yang dapat diambil dari kegitan pendampingan literasi digital. Kegiatan pengabdian ini dilaksanakan di SMP Aisyiyah Muhammadiyah 3 Malang dengan melibatkan 12 siswa kelas 7 dan 8. Karena kondisi masih pademi Covid-19, sehingga metode pada pengabdian ini dilakukan secara daring melalui Whatsapp grup dan pembimbingan melalui video call. Penggunaan aplikasi Whatsapp dipilih karena siswa tidak mengalami kesulitan dan sinyal dapat stabil. Setelah siswa diberi bimbingan, siswa dapat membuat postingan pada media sosial dengan kreatif dengan memanfaatkan media yang ada.
\end{abstract}

Kata Kunci: Literasi, Digital, Sekolah Menengah Pertama.

Abstract: Adolescence is a transitional period from childhood to adulthood. Adolescence is usually followed by a process of self-discovery. In this case, usually adolescents want to find out something they don't know, want their existence to be noticed, and tend to hang out more with their peers. Current technological developments also greatly affect the development of adolescents. Each student has one device that can be used to communicate and access various information that can support their learning. Therefore, digital literacy assistance is needed for junior high school students. This service is carried out in three stages, including the preparation stage, the implementation stage, and the reflection stage. The preparation stage consists of coordination with the school and coordination with student assistants. The implementation stage consists of providing material, discussion, mentoring students, and student products. Then the reflection stage consists of things that can be taken from digital literacy mentoring activities. This service activity was carried out at SMP Aisyiyah Muhammadiyah 3 Malang involving 12 students in grades 7 and 8. Because conditions are still on Covid-19, so the method.

Keywords: literacy, digital, junior high school.

\section{Pendahuluan}

Bisa dikatakan cara penyebaran informasi saat ini berorientasi pada media sosial. Media sosial dapat menyebarkan berita dalam skala besar dan cepat, terlepas dari apakah 
konten beritanya benar atau tidak. Masyarakat dapat membuat media online sendiri untuk mengutarakan pendapat dan mempublikasikan berita, baik berdasarkan sumber yang dapat dipercaya, atau sekedar untuk mengutarakan pendapatnya, atau bahkan menyebarkan derajat kenakalan. Media sosial sepertinya sudah menjadi ketagihan bagi masyarakat Indonesia, khususnya remaja. Tidak mungkin memisahkan remaja dari gadget selama hampir 24 jam untuk terus memperbarui media sosial mereka. Saat ini, media sosial yang paling banyak digunakan oleh para remaja adalah Facebook, Whatsapp, YouTube, Twitter, dan Instagram. Media sosial memberikan banyak kemudahan, sehingga remaja yang menggunakannya dalam waktu lama akan betah.

Riset yang dilakukan bekerja sama dengan Hootsuite dalam "Digital Aroud the World 2019" yang diselenggarakan oleh We Are Social menunjukkan bahwa 130 juta orang Indonesia aktif di media sosial. Laporan tersebut juga menunjukkan bahwa total penduduk Indonesia adalah 265,4 juta, yang separuhnya menggunakan atau mengakses Internet. Orang Indonesia menggunakan Internet, termasuk akses ke media sosial. Hasil riset juga menunjukkan ada 132,7 juta pengguna internet aktif, sebanyak 130 juta. Angka ini juga berarti lebih dari separuh penduduk Indonesia melek media sosial. ((https://www.beritasatu.com/nasional/550691/saatremaja-tak-bisa-kendalikan-diri-di-media-sosial).

Jumlah pengguna internet di seluruh dunia telah mencapai 31,7 miliar, dan jumlah pengguna internet meningkat menjadi 7,6\% dari tahun ke tahun. Sementara pengguna media sosial sendiri mencapai 2,2 miliar, sedangkan pengguna mencapai 3,7 miliar. Fokus utama studi ini adalah pertumbuhan pesat jumlah pengguna internet sosial. Menurut data Kementerian Komunikasi dan Informatika Republik Indonesia, Indonesia sendiri terdiri dari 80\% kelompok usia 15-19 tahun. Padahal, remaja hanya memanfaatkannya untuk kebutuhan pendidikan, tapi juga untuk hiburan, belanja, media sosial, dan lain-lain (Noviandari, 2015).

Media sosial merupakan media online yang dapat digunakan pengguna untuk menjalin pertemanan, mengasah kreativitas dan bertransaksi. Komunitas dapat menggunakan media sosial untuk berpartisipasi, berbagi, dan membuat konten yang meliputi blog, jejaring sosial, Wiki, forum, dan dunia virtual. Blog, jejaring sosial, dan Wiki adalah bentuk media sosial yang paling umum digunakan oleh orang-orang di seluruh dunia (Gani, 2020).

Penggunaan media sosial oleh remaja dapat berdampak positif, baik positif maupun negatif. Penggunaan media sosial yang berlebihan akan sangat mengganggu pembelajaran siswa. Kebiasaan remaja memberikan konten atau mengomentari media sosial seringkali menimbulkan masalah ketika mereka tidak dapat menggunakan media sosial dengan bijak. Apabila masalah ini tidak diselesaikan dengan baik maka akan menimbulkan banyak kerugian bagi kaum muda, yang tentunya akan mengganggu kesehatan mental dan produktivitas mereka selama masa remaja. Remaja dapat diartikan sebagai seseorang yang sudah mucul gejala seksualitas (pubertas). Gejala seksual tersebut biasanya berlangsung sejak usia 13 tahun sampai dengan masa menjelang dewasa. Menjelang dewasa ditandai dengan perkembangan organ-organ jasmani tertentu sampai dengan usia 24 tahun (Tari dan Tafonao, 2019).

Menurut (Gani, 2020) Masa remaja merupakan masa transisi dari masa kanak-kanak hingga dewasa, dengan rentang usia antara 12-22 tahun. Usia ini adalah proses kedewasaan bagi setiap orang. Kedewasaan ini ditandai dengan perubahan fisik dan psikologis.

Remaja adalah individu yang berbeda dengan anak-anak dan orang dewasa. Masa remaja adalah masa transisi. Oleh karena itu, dibutuhkan ketrampilan untuk memahami anak muda. Menurut Organisasi Kesehatan Dunia, remaja dapat dijelaskan secara konseptual. Artinya, dapat menunjukkan standar dalam aspek biologi, psikologi, dan sosial ekonomi. Secara biologis, remaja dapat menunjukkan perubahan seksual. Secara psikologis remaja mengalami perkembangan psikologis dan pola perkembangan dari masa kanak-kanak hingga dewasa. 
Bersamaan dengan itu, secara sosial dan ekonomi, terjadi pergeseran dari ketergantungan ke kemandirian (Wahidi, 2017).

Banyak remaja yang menggunakan media sosial tanpa kontrol diri. Salah satunya permasalahan perundungan (bullying) pada media sosial. Beberapa kasus perundungan pada media sosial atau cyber bullying berakhir pada penjara hingga bunuh diri. Contoh kasus yang terjadi pada tahun 2019 yang melibatkan seorang remaja perempuan hingga bunuh diri. Remaja tersebut berkenalan dengan lawan jenis melalui sosial media dan diminta untuk mengirimkan foto pada bagian tubuh sensitif. Foto tersebut tersebar luas di sosial media, hingga remaja putri tersebut mendapatkan perundungan. Tidak tahan dengan perundungan tersebut, dia akhirnya memilih untuk bunuh diri.

Bullying dapat dipahami sebagai serangan berulang secara fisik, mental, sosial atau verbal. Gunakan kekuatan yang dapat memberikan kepuasan atau manfaat dalam situasi yang tepat untuk aktivitas ini. Bullying adalah bentuk awal dari perilaku agresif, bisa berupa bahasa kasar, kekerasan fisik, dan psikis. Bullying biasanya dilakukan oleh sekelompok bos (Muzdalifah, 2020).

Bullying menuruut Olweus (1999 dalam Darmayanti, dkk, 2019) diartikan sebagai masalah psikososial dengan terus menerus menghina dan menghina orang lain yang berdampak negatif pada pelaku bully dan korbannya, pelaku memiliki kekuatan lebih dari pada korban. Sejalan dengan kemajuan teknologi, bullying tidak hanya terjadi secara tatap muka, tetapi juga di platform media sosial. Beberapa praktisi pendidikan dapat mengatasi dampak bullying dan meminimalkan jumlah bullying melalui program intervensi yang ditargetkan pada siswa sekolah, yang melibatkan orang tua, teman sebaya, pendidik, konselor sekolah, pengelola sekolah, dan anggota sekolah.

Remaja yang masih labil secara emosi akhirnya lebih mengutamakan emosi daripada kejernihan berpikir (Endah et al., 2017). Mungkin masalah terbesar dengan media sosial dapat diringkas dengan penggunaan singkatan, yaitu, anak-anak dan remaja disebut "TMI", "terlalu banyak informasi" atau "terlalu banyak informasi". Anak-anak dan remaja yang menghabiskan waktu luangnya mengakses media sosial tanpa sadar membocorkan terlalu banyak informasi tentang kehidupan pribadinya, yang dapat menimbulkan masalah, seperti rentan terhadap penindasan maya. Ini karena media sosial telah meningkatkan jumlah dan frekuensi konten, terutama di area yang lebih personal dan mudah dilihat siapa pun. Ketika anak-anak dan remaja menggunakan media sosial untuk mengisi waktu luangnya, keadaan ini semakin parah dan akhirnya mengarah pada kecanduan. TMI mendorong kemungkinan tindakan lain, yang disebut FOMO, takut ketinggalan atau "takut ketinggalan berita terbaru".

FOMO mendorong anak-anak dan remaja untuk terus mencari dan berbagi informasi di Internet melalui media sosial. Pada tahap inilah anak-anak dan remaja sangat rentan terhadap risiko predator online, pornografi, kekerasan, penindasan maya, pelanggaran privasi, dan pencurian identitas. Dampak negatif lain dari media sosial adalah semakin jauhnya jarak antara anak dan keluarganya. Istilah yang digunakan oleh anak-anak dan remaja adalah: strategi "dekat dan jauh", dan strategi "jauh dan dekat". Ini dapat menggambarkan bagaimana melihat anak-anak dan remaja di sekitar orang tua dan anggota keluarga mereka, tetapi banyak menggunakan media sosial. Sebaliknya, dalam lingkungan privat / keluarga, mereka justru lebih dekat dengan teman atau orang di media sosial. Oleh karena itu, diperlukan dukungan semua pihak untuk mengontrol generasi muda agar dapat menggunakan media sosial dengan bijak.

Untuk fenomena tersebut diperlukan pembinaan agar remaja lebih bijak dan bertanggung jawab dalam menggunakan media sosial. Salah satunya adalah literasi digital. Literasi digital dapat diartikan sebagai sikap, minat, dan kemampuan pribadi yang baik untuk mengakses, 
mengelola, mengintegrasikan, menganalisis, dan mengevaluasi informasi. Literasi digital juga dapat memberikan pengetahuan baru dan menciptakan pengetahuan baru, yang dapat menjalin komunikasi baru dengan masyarakat (Setyaningsih, dkk, 2019).

Masyarakat sangat membutuhkan literasi digital. Literasi digital juga sangat penting bagi kaum muda. Remaja dapat menyaring informasi yang ditampilkan di media sosial. Literasi digital dapat digunakan untuk memberikan kemampuan dalam memahami, menganalisis, mengevaluasi, mengatur, dan mengevaluasi informasi dengan menggunakan teknologi digital. Literasi anak muda juga harus diperhatikan. Ini karena literasi buruk bagi psikologi anak muda. Gangguan serius ini terjadi karena remaja masih labil secara emosi dan masih mencari informasi tanpa menemukan sumbernya. Adanya literasi juga berdampak pada kepribadian anak muda (Pratiwi dan Pritanova, 2017).

Pada dasarnya, remaja adalah kekayaan negara dan harus diberi pembinaan yang tepat. Oleh karena itu, salah satu tugas yang dapat membimbing siswa untuk menggunakan media sosial dengan bijak adalah memberikan banyak bantuan agar remaja dapat mengelola media sosial untuk kegiatan yang aktif dan kreatif. Hal ini dapat dimulai di SMP Muhammadiyah 3 Malang yang seluruh siswanya berusia remaja dan sangat membutuhkan pendampingan. Siswa SMP Muhammadiyah 3 Malang belum pernah mendapatkan pendampingan pengelolaan media sosial untuk kegiatan yang kreatif dan positif, dengan demikian media sosial yang dimilinya hanya untuk menunjukkan eksistensi mereka. Jika hal ini dibiarkan akan mempengaruhi tumbuh kembang mereka. Dengan demikian, siswa SMP Muhammadiyah 3 Malang perlu diarahkan agar kelak mereka menjadi generasi penerus yang berkualitas dan berkarakter.

\section{Metodologi}

Pengabdian ini dilaksanakan pada tanggal 24 Juli - 29 Agustus 2020. Peserta kegiatan berjumlah 12 Siswa kelas VII dan VII SMP Aisyiyah Muhammadiyah 3 Malang. Kegiatan ini dilakukan secara daring. Hal tersebut disebabkan karena kota Malang merupakan zona merah Covid-19 dan tidak memungkinkan untuk bertatap muka dengan siswa. Media yang digunakan untuk kegiatan daring yaitu Whatsapp Grup dan Video Call. Media tersebut dipilih karena semua siswa mempunyai media tersebut dan tidak mengalami kesulitan ketika menggunakannya.

Bentuk kegiatan pengabdian adalah diskusi. Materi disampaikan oleh pengabdi melalui WA Grup. Setelah itu siswa mempelajari dan memahami materi yang diberikan kemudian dilanjutkan diskusi dengan siswa. Materi pengabdian diberikan sesuai dengan jadwal yang sudah ditentukan sebagai berikut:

Tabel 1. Jadwal Kegiatan Pengabdian

\begin{tabular}{|c|c|c|c|}
\hline No & Hari/Tanggal & Kegiatan & Keterangan \\
\hline 1 & Jumat, 24 Juli 2020 & $\begin{array}{c}\text { Pemberian materi } \\
\text { Penggunaan Internet }\end{array}$ & Pemateri: Hidayah Budi Qur'ani \\
\hline 2 & Sabtu, 25 Juli 2020 & $\begin{array}{c}\text { Pemberian materi } \\
\text { Hubungan Bahasa } \\
\text { dengan Internet }\end{array}$ & Pemateri : Purwati Anggraini \\
\hline 3 & Sabtu, 1 Agustus 2020 & $\begin{array}{c}\text { Pemberian materi } \\
\text { Bijak Bermedia } \\
\text { Sosial }\end{array}$ & Pemateri : Purwati Anggraini \\
\hline 4 & Jumat, 7 Agustus 2020 & $\begin{array}{c}\text { Pemberian materi } \\
\text { Kreativitas dalam } \\
\text { Bermedia Sosial }\end{array}$ & Pemateri: Hidayah Budi Qur'ani \\
\hline 5 & Jumat, 14 Agustus 2020 & Pendampingan & Tim \\
\hline
\end{tabular}




\begin{tabular}{|c|c|c|c|}
\hline & & $\begin{array}{c}\text { penggunaan media } \\
\text { sosial }\end{array}$ & Tim \\
\hline 6 & Sabtu, 15 Agustus 2020 & $\begin{array}{c}\text { Pendampingan } \\
\text { penggunaan media } \\
\text { sosial }\end{array}$ & Tim \\
\hline 7 & Jumat, 21 Agustus 2020 & $\begin{array}{c}\text { Pendampingan } \\
\text { penggunaan media } \\
\text { sosial }\end{array}$ & Tim \\
\hline 8 & Sabtu, 22 Agustus 2020 & $\begin{array}{c}\text { Pendampingan } \\
\text { penggunaan media } \\
\text { sosial }\end{array}$ & Tim \\
\hline 9 & Jumat, 28 Agustus 2020 & $\begin{array}{c}\text { Pendampingan } \\
\text { penggunaan media } \\
\text { sosial }\end{array}$ & Tim \\
\hline 10 & Sabtu, 29 Agustus 2020 & $\begin{array}{c}\text { Pendampingan } \\
\text { penggunaan media } \\
\text { sosial }\end{array}$ & \\
\hline
\end{tabular}

\section{Hasil dan Pembahasan}

Pengabdian dilakukan dalam tiga tahap, yaitu tahap persiapan, tahap implementasi, dan tahap refleksi. Tahap persiapan meliputi koordinasi dengan sekolah dan koordinasi dengan asisten siswa. Tahap implementasi meliputi pemberian materi, diskusi, pembinaan siswa dan produk pembelajaran. Kemudian tahap refleksi mencakup apa saja yang bisa didapat dari kegiatan pendampingan literasi digital. Tiga tahap pengabdian dijelaskan di bawah ini.

\section{A. Hasil}

\section{Tahap Persiapan}

Sebelum kegiatan pengabdian dimulai, pengabdi melakukan tahap persiapan. Tahap persiapan ini dilakukan agar seluruh rangkaian kegitan pengabdian dapat terlaksana dengan baik. Pada tahap persiapan, kegiatan yang dilakukan adalah koordinasi dengan pihak sekolah dan koordinasi dengan pendamping siswa. Deskripsi kegiatan tersebut dijelaskan di bawah ini.

\section{a. Koordinasi dengan Guru Pendamping Siswa}

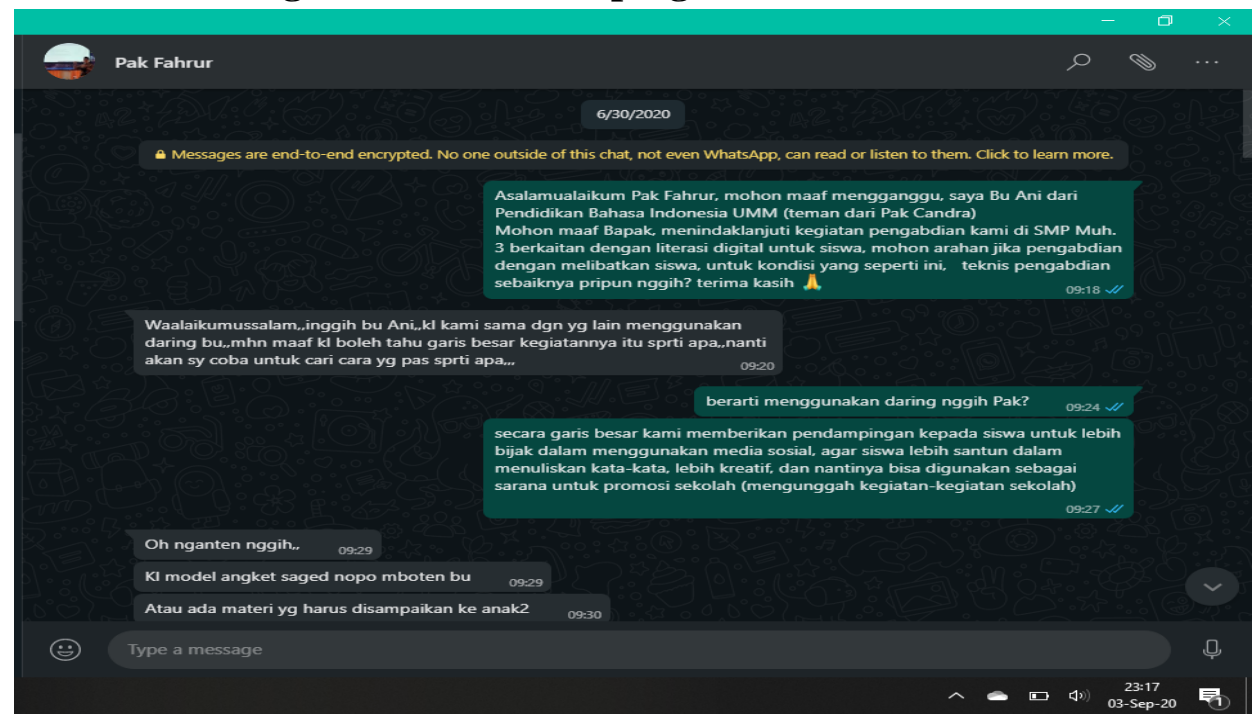

Gambar 1. Koordinasi Tim Pengabdian dengan Waka Kurikulum 


\section{b. Koordinasi dengan Guru Pendamping Siswa}

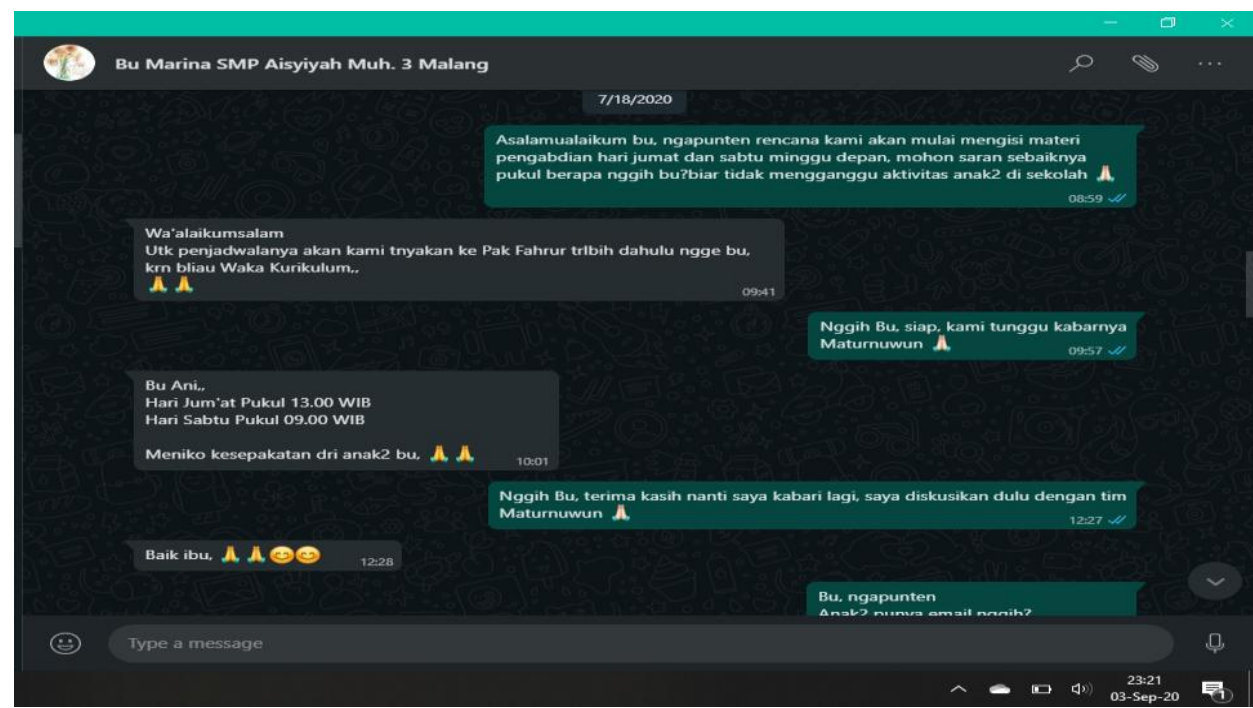

Gambar 2. Koordinasi dengan Guru Pendamping Siswa

\section{Tahap Pelaksanaan}

Setelah melakukan persiapan dengan berkoordinasi dengan pihak sekolah dan guru pendamping. Selanjutnya adalah tahap pelaksanaan. Pada tahap pelaksanaan ini, tim pengabdian sudah menyiapkan materi yang akan diberikan kepada siswa dan teknis pelaksanaannya. Pada tahap pelaksanaan dibagi menjadi tiga kegiatan. Kegiatan pertama yaitu pemberian materi, tahap kedua diskusi dengan siswa, dan tahap ketiga yaitu pendampingan sampai dengan menghasilkan produk yang kreatif, sopan, memberikan motivasi, dan dapat dipertanggungjawabkan ke media sosial.

\section{a. Pemberian Materi Literasi Digital}

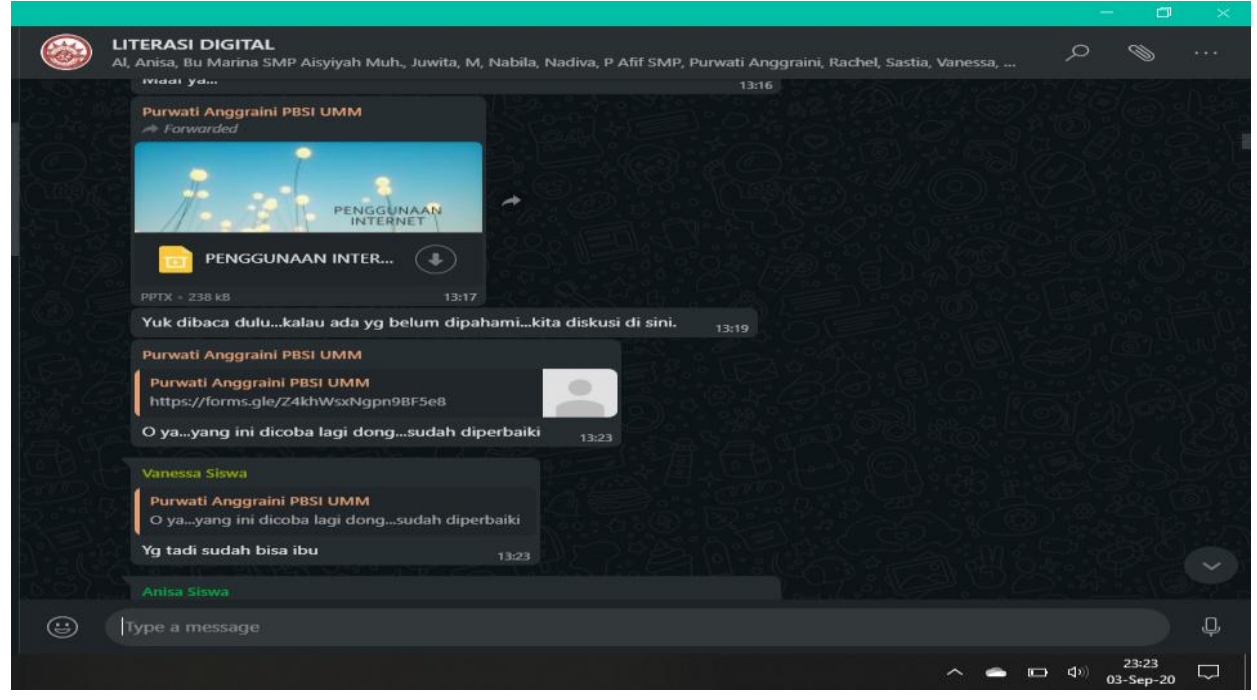

Gambar 3. Pemberian Materi Literasi Digital 


\section{b. Diskusi Bersama Siswa}

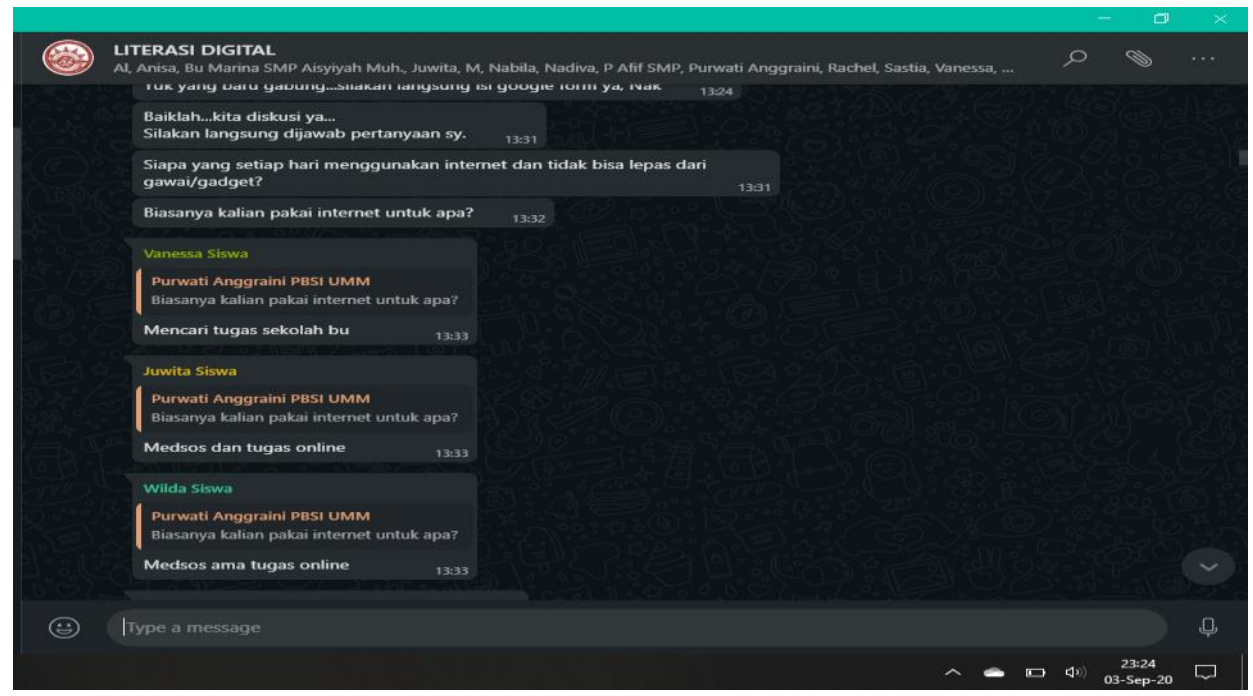

Gambar 4. Diskusi Bersama Siswa

\section{c. Pendampingan Siswa}

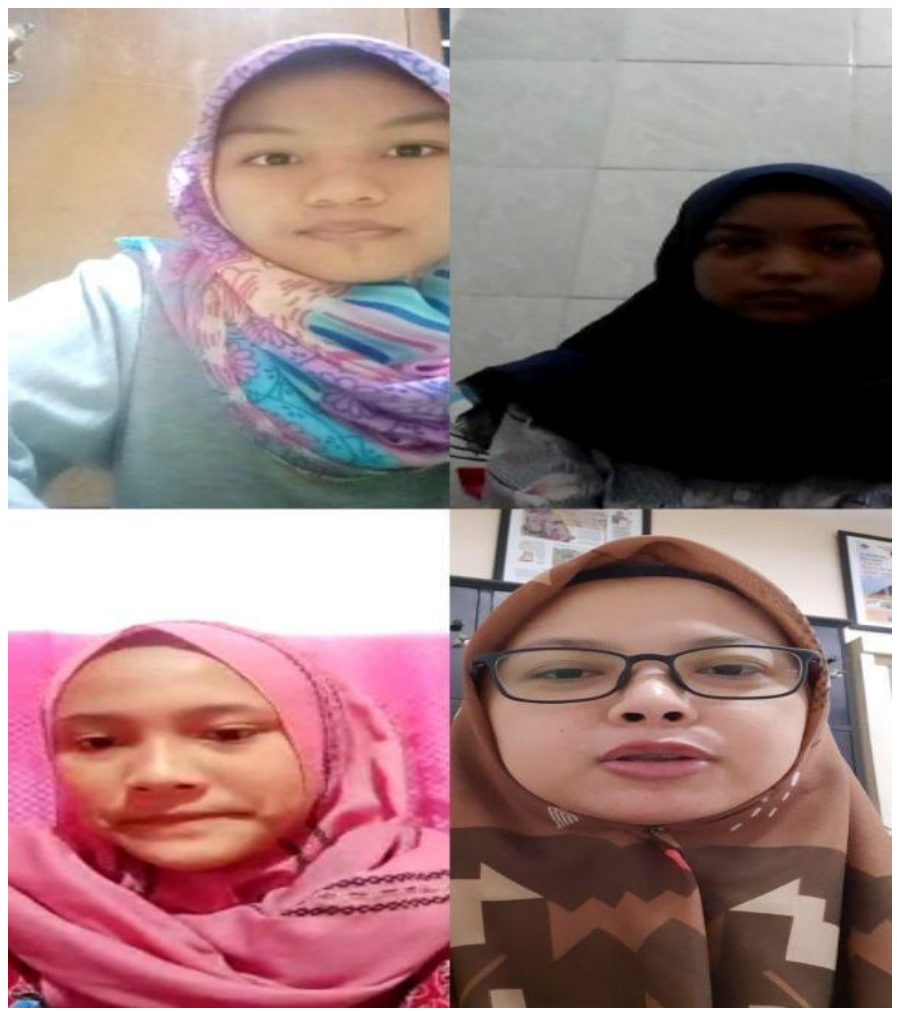

Gambar 5. Proses Pendampingan Siswa 


\section{d. Produk Literasi Siswa}
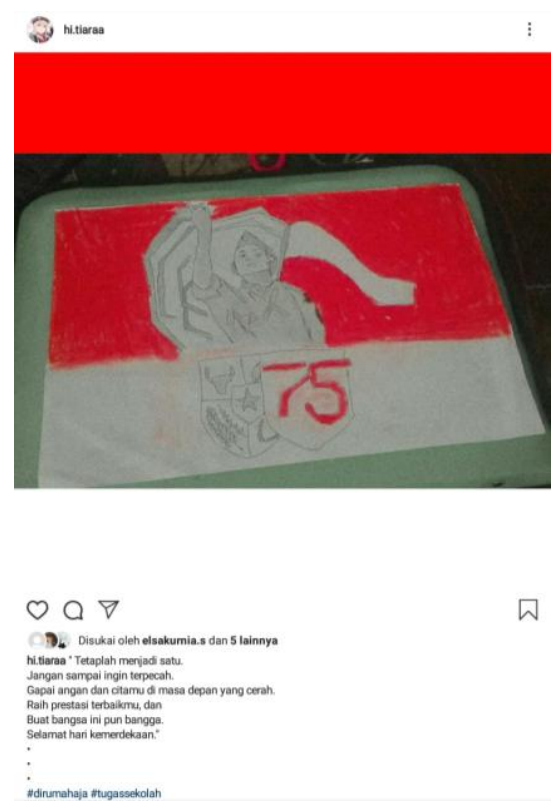

ఐ
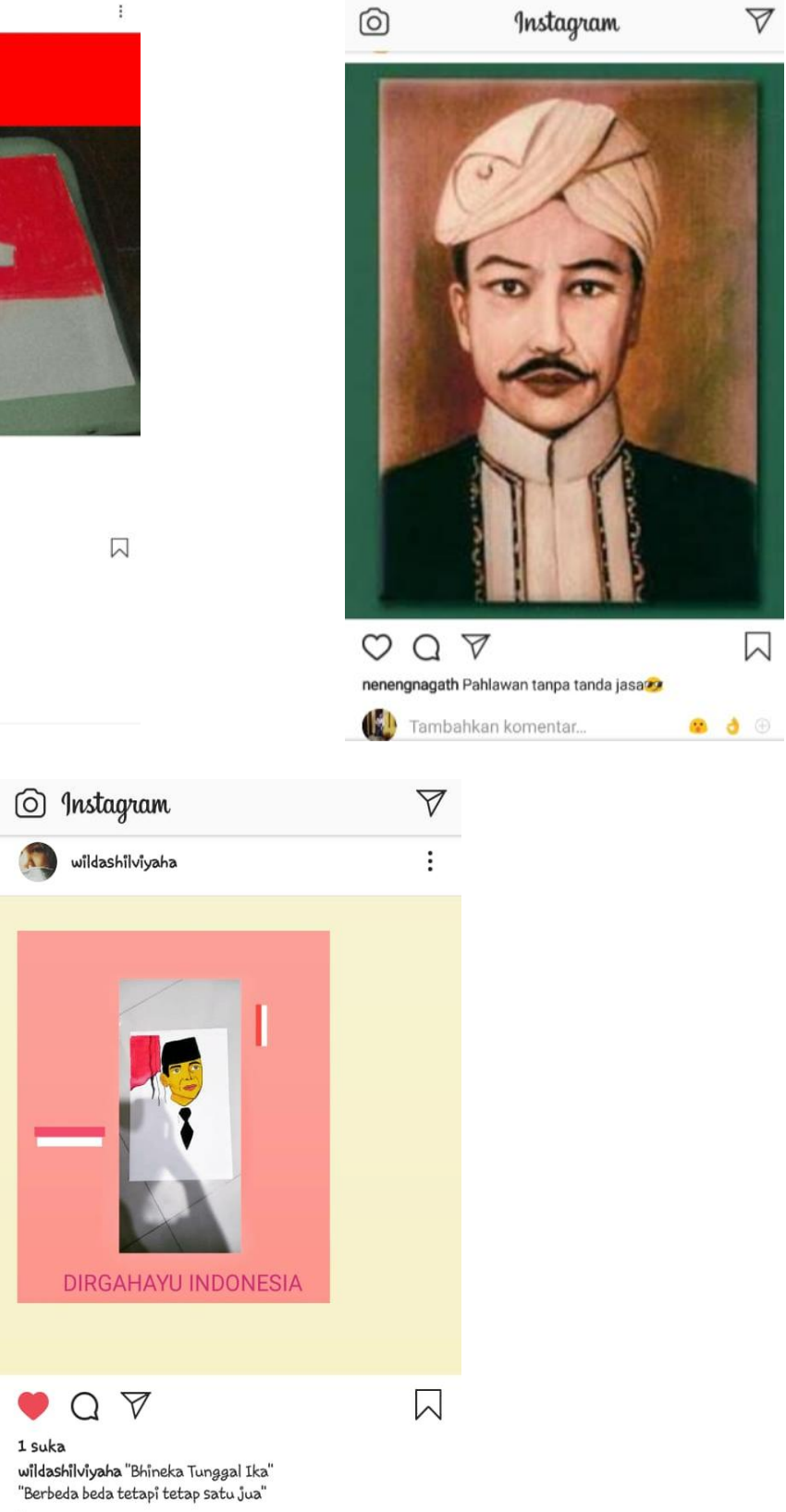

Gambar 6a. Konten Media Sosial Sebelum Revisi 

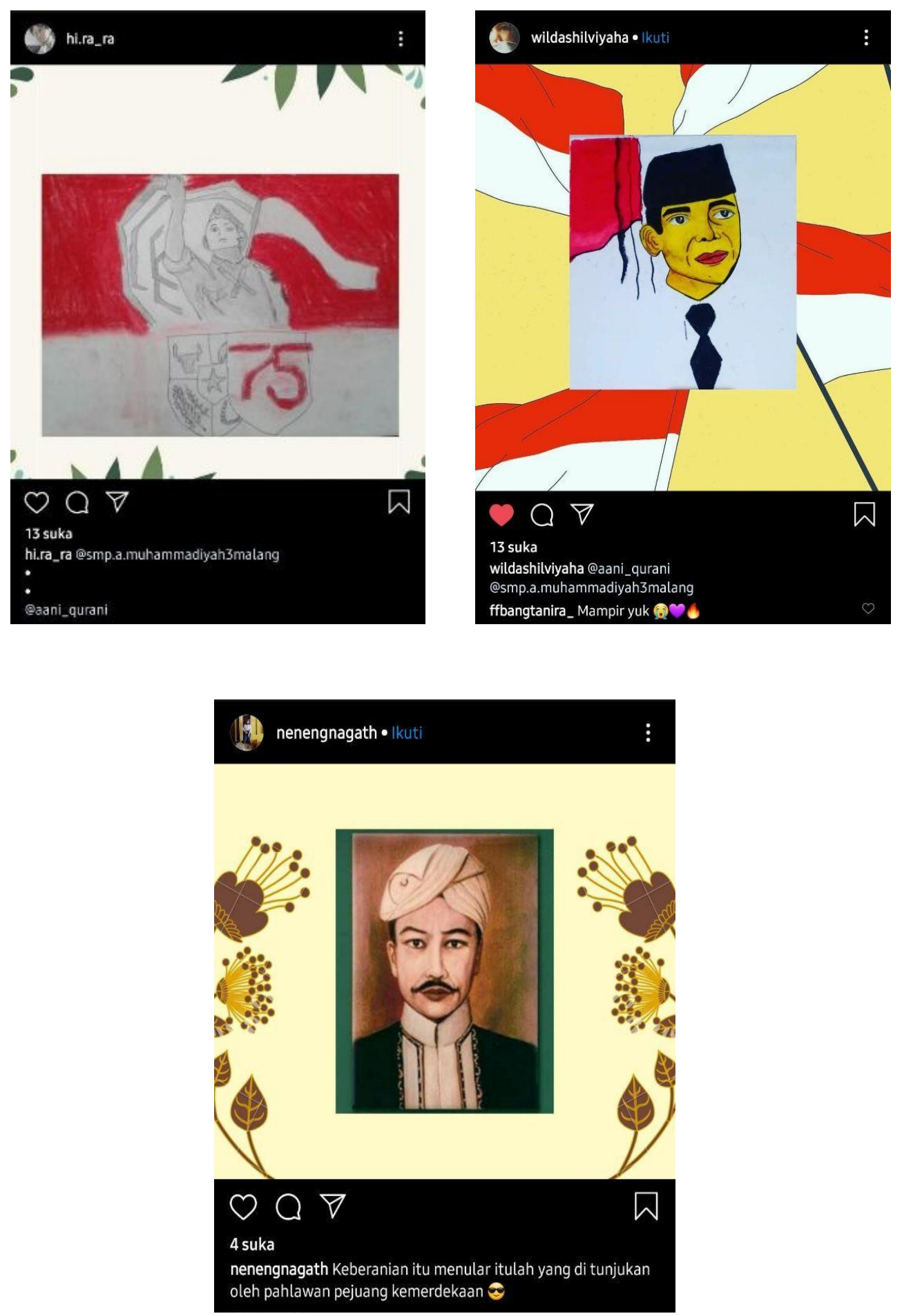

Gambar 6b. Konten Media Sosial Setelah Revisi 


\section{Tahap Refleksi}

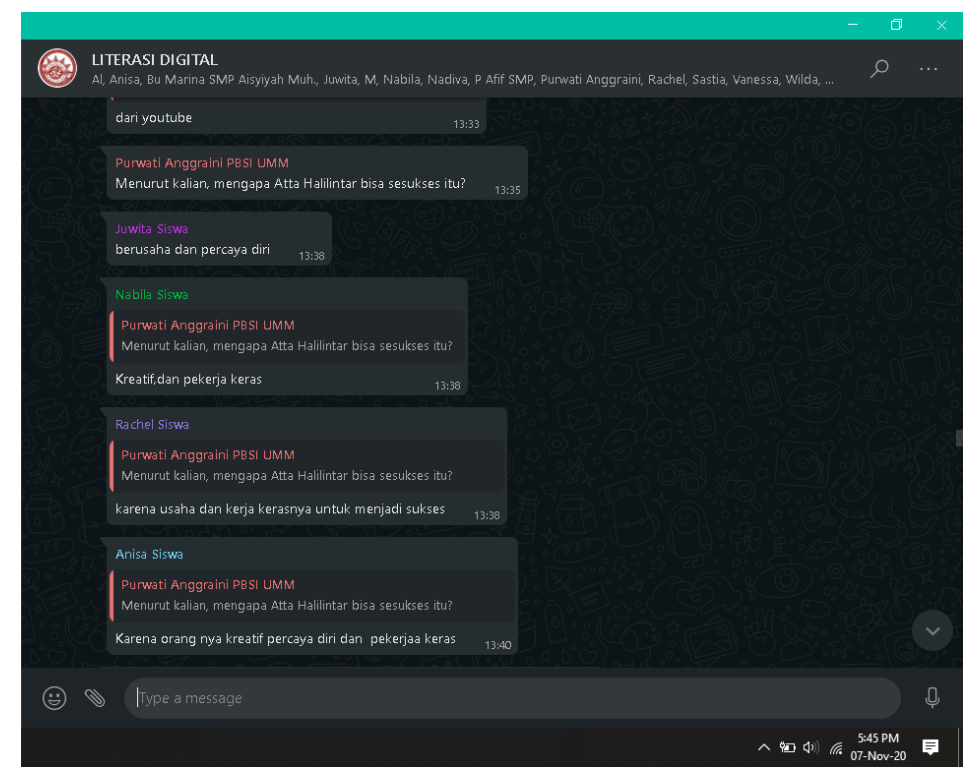

Gambar 7. Siwa Melakukan Refleksi Kegiatan dengan Tim Pengabdian

\section{B. Pembahasan}

\section{Tahap Persiapan}

Sebelum melakukan pengabdian, tim pengabdi melakukan koordinasi dengan pihak sekolah. hal tersebut bertujuan agar jadwal yang sudah ditawarkan oleh tim tidak mengganggu kegiatan belajar siswa. Tim melakukan koordinasi dengan Waka Kurikulum. Ketika koordinasi dengan Waka Kurikulum, tim pengabdian menanyakan waktu yang sesuai untuk memberikan materi dan teknis pemberian materi. Hal tersebut dilakukan agar siswa merasa nyaman dan tidak mengganggu kegiatan belajar siswa. Selama masa pandemi Covid-19, koordinasi dengan Waka Kurikulum dilakukan secara daring yaitu menggunakan Whatsapp.

Selain berkoordinasi dengan Waka Kurikulum, tim pengabdian juga berkoordinasi dengan guru pendamping siswa. Guru pendamping siswa ditunjuk oleh pihak sekolah untuk memantau dan mendampingi siswa selama kegiatan pengabdian. Tugas guru pendamping adalah memantau keaktifan siswa dan memberikan motivasi kepada siswa. Tim pengabdian dan guru pendamping berkoordinasi sebelum pelaksanaan kegiatan. Koordinasi ini meliputi jumlah siswa yang bersedia mengikuti kegiatan literasi, identitas siswa, nomor handphone siswa, dan teknis pemberian materi. Koordinasi tim pengabdian dengan guru pendamping dilakukan secara daring menggunakan Whatsapp.

\section{Tahap Pelaksanaan}

Setelah melakukan koordinasi dengan pihak sekolah, tim pengabdi kemudian membuat grup Whatsapp yang bernama Literasi Digital. Grup WA Literasi digital dibuat untuk memudahkan komunikasi dengan siswa. Grup Whatsapp ini dipilih karena semua siswa menggunakan aplikasi ini. Pemberian materi dilakukan secara bertahap sesuai dengan jadwal yang sudah disepakati.

Tim memberikan materi melalui WA Grup, kemudian memberikan waktu 30 menit kepada siswa untuk membaca dan memahami materi. Materi dibuat dengan cara yang menarik dan menggunakan bahasa yang sederhana untuk memudahkan siswa dalam memahaminya. 
Setelah materi disampaikan dan siswa memahami isi materi, kegiatan selanjutnya adalah diskusi. Diskusi ini dilakukan untuk mengetahui tingkat pemahaman siswa terhadap materi yang dikenalkan. Diskusi juga diadakan untuk memperjelas apakah ada materi yang kurang dipahami atau dipahami siswa. Kegiatan diskusi juga dipandu oleh seorang guru pendamping. Guru pendamping memotivasi siswa untuk tetap aktif. Oleh karena itu, kegiatan diskusi berjalan dengan lancar.

Setelah mendapatkan materi dan berdiskusi, kemudian siswa dibagi menjadi kelompokkelompok kecil. Setiap kelompok terdiri dari tiga siswa. Pengelompokan ini bertujuan agar siswa lebih fokus dan memahami instruksi yang diberikan oleh tim pengabdian. Dalam pendampingan ini, siswa diminta untuk membuat konten kemudian diposting ke dalam media sosial berupa Instagram. Selanjutnya, tim pengabdi memberikan arahan kepada siswa melalui video call Whatsapp. Pendampingan ini bertujuan agar siswa lebih memahami konten yang diposting. Selain itu, tim pengabdian juga memberikan masukan-masukan agar postingan siswa lebih menarik. Setelah mendapatkan masukan, siswa kemudian memposting ulang konten tersebut sesuai dengan arahan tim pengabdian.

Kegiatan pengabdian ini mempunyai luaran yaitu produk literasi siswa berupa postingan siswa pada media sosial. Produk siswa dalam bentuk konten Instagram dibagi menjadi dua bentuk. Pertama, postingan siswa sebelum mendapatkan materi literasi dan postingan kedua yaitu konten yang sudah mendapatkan materi literasi. Gambar 6a dan 6b menunjukkan bahwa siswa menghasilkan produk berupa konten yang diunggah pada media sosial, khususnya Instagram. Pada gambar 6a tampak bahwa konten yang diunggah siswa masih belum menarik. Hal itu terlihat bahwa gambar yang diposting masih polos dan belum ada variasi kreatifitasnya. Pada gambar 6b, setelah mendapatkan masukan dari tim pengabdian, kemudian siswa merevisi kontan yang diunggah. Hal itu terlihat pada gambar yang diunggah lebih menarik dan sesuai dengan tema yaitu kemerdekaan. Selain itu, dapat dilihat bahwa postingan yang diunggah mendapatkan like atau disukai lebih banyak dari postingan sebelumnya.

\section{Tahap Refleksi}

Pada tahap refleksi, semua siswa dikumpulkan dalam forum WA Grup. Kegiatan refleksi ini bertujuan untuk mencari tahu sejauh mana pemahaman siswa mengenai literasi digital. selain itu, dalam kegiatan refleksi, siswa juga dapat menyampaikan pengalaman-pengalaman yang diperoleh ketika mendapatkan materi pertama hingga tahap pendampingan. Dari gambar 7, dapat dilihat bahwa setelah kegiatan persiapan sampai dengan pelaksanaan terlaksana, tim pengabdian melakukan refelksi bersama siswa. Siswa sangat antusias dalam melakukan refleksi kegiatan. Siswa memperoleh banyak ilmu mengenai literasi digital. Hal itu dapat memberikan bekal pengetahuan kepada siswa untuk lebih bijak dan bertanggung jawab dalam menggunakan media sosial.

\section{Simpulan}

Kegiatan pengabdian literasi digital yang diikuti oleh siswa SMP Aisyiyah Muhammadiyah 3 Malang berjalan dengan baik. Hal itu terlihat dari antusias siswa yang aktif mengikuti kegiatan pengabdian literasi digital. Siswa mendapatkan ilmu mengenai pemanfaatan media sosial untuk kegiatan positif dan kreatif. Sebelum mendapatkan materi mengenai literasi digital, siswa memposting gambar di Instagram dengan konten yang kurang menarik. Akan tetapi, setelah mendapatkan materi mengenai literasi digital, konten yang diposting oleh siswa lebih menarik dan kreatif. Kegiatan pengabdian ini akan dilanjutkan dengan pembuatan konten media sosial yang berfungsi sebagai promosi sekolah. 


\section{Ucapan Terima Kasih}

Tim pengabdian kegiatan Literasi Digital Bagi Siswa Sekolah Menengah Pertama Aisyiyah Muhammadiyah 3 Malang mengucapkan terima kasih kepada Direktorat Penelitian dan Pengabdian Kepada Masyarakat (DPPM) Universitas Muhammadiyah Malang yang telah memberikan kesempatan untuk mengakses program pengabdian. Kepala sekolah, Waka Kurikulum, dan guru pendamping SMP Aisyiyah Muhammadiyah 3 Malang yang telah memberikan kesempatan dan mendukung kegiatan pengabdian ini. Siswa-siswa peserta pengabdian literasi yang telah mengikuti kegiatan secara aktif dan antusias.

\section{Daftar Pustaka}

Darmayanti, K. K. H., Kurniawati, F., \& Situmorang, D. D. B. (2019). Bullying di sekolah: Pengertian, dampak, pembagian dan cara menanggulanginya. PEDAGOGIA, 17(1), 5566.

Endah, T., Dimas, A., \& Akmal, N. (2017). Kajian dampak penggunaan media sosial bagi anak dan remaja.

Gani, A. G. (2020). Pengaruh Media Sosial Terhadap Perkembangan Anak Remaja. JURNAL MITRA MANAJEMEN, 7(2).

https://www.beritasatu.com/nasional/550691/saat-remaja-tak-bisa-kendalikan-diri-di-mediasosial diakses pada tanggal 3 September 2020.

Muzdalifah, Muzdalifah. "BULLYING." AL-MAHYRA (Jurnal Penelitian Dan Pengembangan Keilmuan) 1, no. 1 (2020): 50-65.

Noviandari, L. (2015, Agustus 18). Statistik Pengguna Internet dan Media Sosial Terbaru 2015. Dipetik Oktober 22, 2015, dari techinasia: https://id.techinasia.com/

Pratiwi, N., \& Pritanova, N. (2017). Pengaruh literasi digital terhadap psikologis anak dan remaja. Semantik, 6(1), 11-24.

Setyaningsih, Rila, Abdullah Abdullah, Edy Prihantoro, and Hustinawaty Hustinawaty. "Model Penguatan Literasi Digital Melalui Pemanfaatan E-Learning." Jurnal ASPIKOM 3, no. 6 (2019): 1200-1214.

Tari, E., \& Tafonao, T. (2019). Tinjauan Teologis-Sosiologis terhadap Pergaulan Bebas Remaja. DUNAMIS: Jurnal Teologi dan Pendidikan Kristiani, 3(2), 199-211.

Wahidin, U. (2017). Pendidikan Karakter Bagi Remaja. Edukasi Islami: Jurnal Pendidikan Islam, 2(03). 